Revista Complutense de Historia de América

ISSN: 1132-8312

http://dx.doi.org/10.5209/RCHA.61084

\title{
Autoridades y conflictos de jurisdicción en "pueblos de indios". Córdoba, Gobernación del Tucumán, 1750-1810
}

\author{
Sonia Tell ${ }^{2}$
}

Recibido: 8 de febrero de 2016/ Aceptado: 19 de julio de 2016

Resumen. En este artículo se aborda la administración de gobierno y justicia en los "pueblos de indios" de Córdoba entre 1750 y 1810, período caracterizado por el crecimiento demográfico de la mayoría de los pueblos que habían persistido hasta entonces, el final del proceso de disolución de la encomienda privada iniciado a principios del siglo XVIII y las reformas de los Borbones en el ramo de tributo, procesos que contribuyeron a fortalecer a las autoridades indígenas, a las que se asignaron responsabilidades de empadronamiento, cobro del tributo y administración de justicia. En primer lugar, se identifican atribuciones de caciques, alcaldes y regidores indígenas; a continuación, se examinan las competencias de gobierno, justicia y policía de otras autoridades (capitanes recaudadores de tributo, curas doctrineros, alcaldes de la hermandad y jueces pedáneos) sobre estos pueblos. Por último, se tratan las contiendas de jurisdicción entre ambos grupos de autoridades, que se produjeron por el ejercicio de la jurisdicción criminal sobre los pueblos y sus habitantes, especialmente los foráneos identificados como mestizos o "castas". Estos temas se consideran en relación con el proceso de adaptación y resistencia al dominio colonial y el acceso de las sociedades indígenas a la justicia española.

Palabras clave: Pueblos de indios; jurisdicción civil y criminal; reformas borbónicas; autoridades indígenas; autoridades españolas; mestizaje; siglos XVIII-XIX.

\section{[en] Authorities and Jurisdictional Conflicts in Indian Towns. Cordoba, Governorship of Tucuman, 1750-1810}

Abstract. In this article we approach the administration of government and justice in the Indian towns of Córdoba between 1750 and 1810. This period was marked by demographic growth in most of the towns that had survived until then, by the end of the process of dissolution of the private encomiendas, initiated at the beginning of eighteenth century, and by the Bourbon tributary reforms - all processes that helped to strenghen the indigenous authorities, to which responsibilities of registration, collection of tribute and administration of justice were assigned. Firstly, we identify the attributions of Indian chefs, indigenous mayors and city councilors; then we examine the competences of government, justice, and police of other authorities (tribute collectors, parish priests, mayors of the brotherhood, and district justices) in these towns. Ultimately, we analyze the jurisdiction conflicts between both groups of authorities, which occurred through the exercise of criminal jurisdiction over the towns and their inhabitants, especially those identified as mestizos or belonging to the castas. These topics are considered in connection with the process of resistance and adaptation to colonial rule, and the access of indigenous societies to Spanish justice.

Keywords: Indigenous Peoples; Civil and Criminal Jurisdiction; Bourbon Reforms; Indigenous Authorities; Spanish Authorities; Miscegenation; 18-19th Centuries.

\footnotetext{
1 Agradezco los comentarios de Silvia Palomeque, Renzo Honores, Darío Barriera, Alejandro Agüero y Edgardo Dainotto a versiones previas de este trabajo, así como las sugerencias de los evaluadores.

2 Instituto de Humanidades, CONICET y Universidad Nacional de Córdoba (Argentina)

E-mail: sotell@ffyh.unc.edu.ar
} 
Sumario. 1. Introducción. 2. Formas de acceso y atribuciones de curacas y cabildos indígenas. 3 . Competencias de alcaldes de la Hermandad, jueces pedáneos y sus auxiliares en pueblos de indios. 4. Conflictos de jurisdicción en los pueblos de indios (1750-1810). 5. Conclusión: Acerca de la jurisdicción sobre indios, mestizos y castas. 6 . Referencias bibliográficas.

Cómo citar: Tell, S. (2018) Autoridades y conflictos de jurisdicción en "pueblos de indios". Córdoba, Gobernación del Tucumán, en Revista Complutense de Historia de América 44, 167-190.

\section{Introducción}

Numerosas investigaciones sobre las instituciones judiciales españolas en América coinciden en destacar la importancia que tuvo el acceso a ese ámbito dentro del repertorio de formas de adaptación, resistencia y resolución de conflictos de las poblaciones amerindias sujetas a dominio colonial. Si en general esta premisa es indiscutida y se acepta que la litigación fue un recurso viable y una forma de ejercicio de la política para los indígenas, donde pusieron a prueba su habilidad para sacar provecho de las contradicciones de intereses entre facciones y autoridades en competencia, la eficacia y la significación que tuvo para sus sociedades han sido objeto de controversia, fundada en las distintas experiencias históricas estudiadas, en las posibilidades de las fuentes disponibles y en los enfoques de investigación adoptados.

Desde la década de 1980, numerosos autores reconocieron que la justicia española permitió a los indígenas canalizar sus protestas sobre tierras, tributo, mita, servicios personales y exacciones diversas, y expidió en muchos casos resoluciones favorables, aunque no siempre estas fueron llevadas a efecto. Uno de los estudios pioneros que permitió comenzar a pensar la participación indígena en el sistema judicial como una práctica política y como un recurso para dirimir tanto conflictos con los colonos europeos, como rivalidades entre comunidades o entre sus miembros, fue el de Stern ${ }^{3}$. Este autor sostuvo que el encuadramiento de las protestas dentro de las instituciones coloniales contribuyó en última instancia a la reproducción de la hegemonía europea, a crear un sentido de legitimidad de la corona española como garante de la preservación de las sociedades indígenas y a desactivar conflictos sociales que pudieran llevar a un ataque radical contra el dominio colonial. Con matices, los elementos centrales de esta perspectiva son compartidos por otros investigadores, tanto para Mesoamérica como para los Andes 4 .

Estudios más recientes han matizado o contradicho esa visión acerca de la hegemonía de la justicia española, presentando al sistema judicial como un campo de confrontación y negociación más ambivalente, que dio margen para que las prácticas indígenas contribuyeran, hasta cierto punto, a modelar el régimen colonial. En debate con Stern, Serulnikov argumentó que las nociones de justicia y legitimidad de la monarquía nutrieron las ideas y prácticas políticas indígenas y llegaron a constituir tanto un instrumento de dominación como una fuente de derechos y expectativas ${ }^{5}$. Asimismo, se ha afirmado que en su esfuerzo creativo por adaptarse a las estructuras del poder español, las poblaciones amerindias contribuyeron a crear una "cultura le-

\footnotetext{
Stern, 1986.

Borah, 1996 [1985]; Katz, 2004 [1990]; Kellogg, 1995; Owensby, 2008, entre otros.

Serulnikov, 2006.
} 
gal colonial" en la que introdujeron sus propias nociones y usos de la justicia ${ }^{6}$. Desde la historia del derecho se plantea que el "pluralismo legal" - esto es, la coexistencia de diversas fuentes de derecho- el lugar dado a la costumbre, la flexibilidad para acomodarse a las condiciones locales y el aliento de la litigiosidad que caracterizaba a las instituciones jurídicas castellanas ${ }^{7}$, proveían un campo fértil para la iniciativa indígena; no obstante estudios del período colonial temprano muestran que esta no fuera en última instancia muy bien vista por las autoridades coloniales, que desarrollaron prontamente esfuerzos para contener los pleitos llevados adelante por los señores étnicos y reducir su autonomía en materia de litigación ${ }^{8}$.

Dentro del campo de los estudios dedicados a la participación indígena en el sistema judicial, son menos los dedicados específicamente a reconstruir el proceso de formación de la "jurisdicción civil y criminal" sobre las reducciones indígenas. No obstante, disponemos de investigaciones pioneras como la de Assadourian para el virreinato del Perú y las elaboradas para otras regiones, como las de Palomeque para Cuenca en la Audiencia de Quito?.

En la Gobernación del Tucumán, las aproximaciones al problema del acceso de los indígenas a la justicia colonial en su mayoría se enmarcaron en estudios más amplios sobre persistencia, adaptación y resistencia de las sociedades nativas bajo dominio español y estuvieron anudadas a la reflexión sobre las especificidades que revistió la invasión española y el dominio colonial temprano en este espacio ${ }^{10}$.

Al respecto, cabe señalar que inicialmente los grupos nativos de esta gobernación fueron organizados mediante la institución de la encomienda privada de servicio personal, cuyas características eran similares a las de las encomiendas del virreinato peruano antes de las Leyes Nuevas ${ }^{11}$. Hasta hace menos de dos décadas, se enfatizó que esta gobernación fue un área de temprana y fuerte desestructuración de las sociedades nativas, debido a la alta tasa de mortalidad, la exigencia incontrolada de servicios personales, la disgregación y desafiliación de población indígena ${ }^{12}$. En este contexto, Córdoba fue vista como uno de los casos extremos: una jurisdicción donde la desestructuración de las sociedades originarias había sido tan temprana y profunda que sus sobrevivientes se habrían extinguido prácticamente hacia el siglo XVIII, por efecto de la mortalidad y el desarraigo en los siglos XVI y XVII, la desaparición de las encomiendas privadas y la dispersión de su escasa población en la primera mitad del siglo XVIII y el crecimiento demográfico de los pueblos de indios activado por el mestizaje en la segunda mitad ${ }^{13}$. De manera similar, desde un enfoque más institucional se sostuvo que el sólido poder de los encomenderos en el Tucumán

\footnotetext{
Kellogg, 1995; Mumford, 2008; Owensby, 2008; Yannakakis, 2013, entre otros.

Véase los estudios de Kagan, 1991, para Castilla, y Cutter, y 1994, para Nueva España.

Véase Honores, 2003, sobre las reformas judiciales implementadas por el virrey Toledo en el Perú.

Assadourian, 1994; Palomeque, 1997 y 2000a.

10 La Gobernación del Tucumán incluía las jurisdicciones de Jujuy, Salta, Tucumán, Santiago del Estero, Catamarca, La Rioja y Córdoba. Formó parte el Virreinato del Perú hasta 1776, cuando pasó a integrar el Virreinato del Río de la Plata y fue dividida en dos gobernaciones intendencias con cabeceras en las ciudades de Salta y Córdoba respectivamente.

11 Véase la síntesis de Palomeque, 2000b, basada en numerosas investigaciones realizadas desde la década de 1980 sobre esta región.

12 Lorandi, 1988.

13 Piana, 1992; Arcondo, 1992; Punta, 1997. Un estado de la cuestión sobre encomiendas y pueblos de indios de Córdoba en Tell - Castro, 2011. Sobre el crecimiento demográfico de estos pueblos en el siglo XVIII, ver Ferrero, 2017.
} 
impidió el acceso de los indígenas a la justicia en los siglos XVI y XVII, o bien su eficacia se redujo porque ese acceso no fue autónomo sino mediado por los mismos encomenderos ${ }^{14}$.

Todos estos planteos fueron matizados por una serie de estudios de caso que demostraron que algunas comunidades indígenas del Tucumán lograron sobrevivir y ser reconocidas como tales hasta los siglos XIX o $\mathrm{XX}^{15}$. De ellos se desprendió que una de las formas más exitosas de resistencia indígena, incluso en la época temprana cuando el acceso a la justicia aún era difícil y poco frecuente, consistió en eludir las instancias inferiores dominadas por la elite encomendera y acceder a instancias superiores como el gobernador o la Audiencia de Charcas, más preocupados por hacer cumplir las leyes que resguardaban en algún grado a la población nativa de la explotación de los colonos ${ }^{16}$.

Además, las nuevas investigaciones sobre encomiendas, tributación y visitas en la Gobernación del Tucumán han puesto de relieve que la intervención de los funcionarios de la corona, aunque débil, no fue inexistente como se pensaba hasta hace poco ${ }^{17}$. En el siglo XVIII, los pueblos de indios y sus autoridades tenían como una herramienta consolidada el recurrir a las instituciones judiciales y a otras instancias de control institucional como las revisitas de los pueblos y -al menos en el caso de Córdoba- encontraron a fines de siglo interlocutores receptivos en los virreyes del Río de la Plata y la Audiencia de Buenos Aires ${ }^{18}$.

Dentro de este panorama, una arista de la relación de los pueblos de indios con las instituciones políticas y judiciales coloniales que no ha sido prácticamente explorada en los territorios de la Gobernación del Tucumán, se refiere a la formación de la jurisdicción civil y criminal sobre la "república de indios" y sus permeables bordes. A diferencia de lo que ocurre con las justicias españolas o hispanocriollas en el período colonial y sus reacomodos en la primera mitad del siglo XIX -que vienen recibiendo sostenida atención por parte de los investigadores especializados ${ }^{19}$ - es poco lo que se sabe sobre la "justicia comunal" 20 , las atribuciones que recibieron o fueron forjando curacas o caciques y cabildos en los pueblos de reducción y los cambios -si los hubo- que pudo traer aparejado el lento proceso de supresión de las encomiendas privadas en estos territorios durante la primera mitad del siglo XVIII. En este trabajo nos proponemos abordar este tema, fundamentalmente mediante el examen de los conflictos entre autoridades que reclamaron jurisdicción criminal sobre los pueblos de indios.

14 Bixio - González, 2003. En ese contexto, se plantea que hubo un deterioro marcado de la autoridad cacical entre los siglos XVI y XVII. Véase González, 2009.

15 Sobre esta evolución consúltese la reflexión de Lorandi, 2002.

16 Palomeque, 2000b; Castro, 2006.

17 Sobre las relaciones de algunos gobernadores del Tucumán con el sector encomendero en el siglo XVII ver Castro, 2013; Carmignani, 2015. De las dos visitas generales a la gobernación por oidores de la Audiencia de Charcas, se dispone solo de los autos de la segunda, la efectuada por el oidor Luján de Vargas en 1692-94. Entre los estudios atentos al desempeño de Luján como juez visitador y a la visita como instancia de castigo a los encomenderos y "desagravio" de la población indígena, cabe destacar los pioneros de Doucet, 1980a y 1980b, y la reciente reevaluación de sus aportes por Castro, 2015a y 2015b. La visita de Córdoba ha sido transcripta y publicada por Bixio - González - Grana - Iarza, 2009.

18 Tell, 2010 y 2012.

19 Véase los estados de la cuestión de Barriera, 2014, sobre el virreinato del Río de la Plata y de Punta, 2009, sobre Córdoba.

20 Tomamos la expresión "justicia comunal” de Guerrero, 2010. 
Dado que no contamos aún con investigaciones sistemáticas sobre las transformaciones que la invasión y consolidación del dominio español indujeron en las formas prehispánicas de ejercicio de la autoridad y los liderazgos étnicos entre las sociedades originarias de este espacio, esperamos aportar información que pueda ser integrada en ese sentido a la que vienen proveyendo los estudios de arqueología y etnohistoria del período colonial temprano. También esperamos contribuir al estudio de las formas de institucionalización del poder político y organización de territorios y jurisdicciones en un período que se sitúa hacia el final de una doble transición: las reformas de los monarcas borbones que afectaron la organización política, administrativa y jurisdiccional de las colonias, y la retroversión de los pueblos de indios de esta región de encomienda privada a la corona, con el consiguiente reordenamiento de autoridades y asignación de responsabilidades de cobro del tributo y administración de justicia.

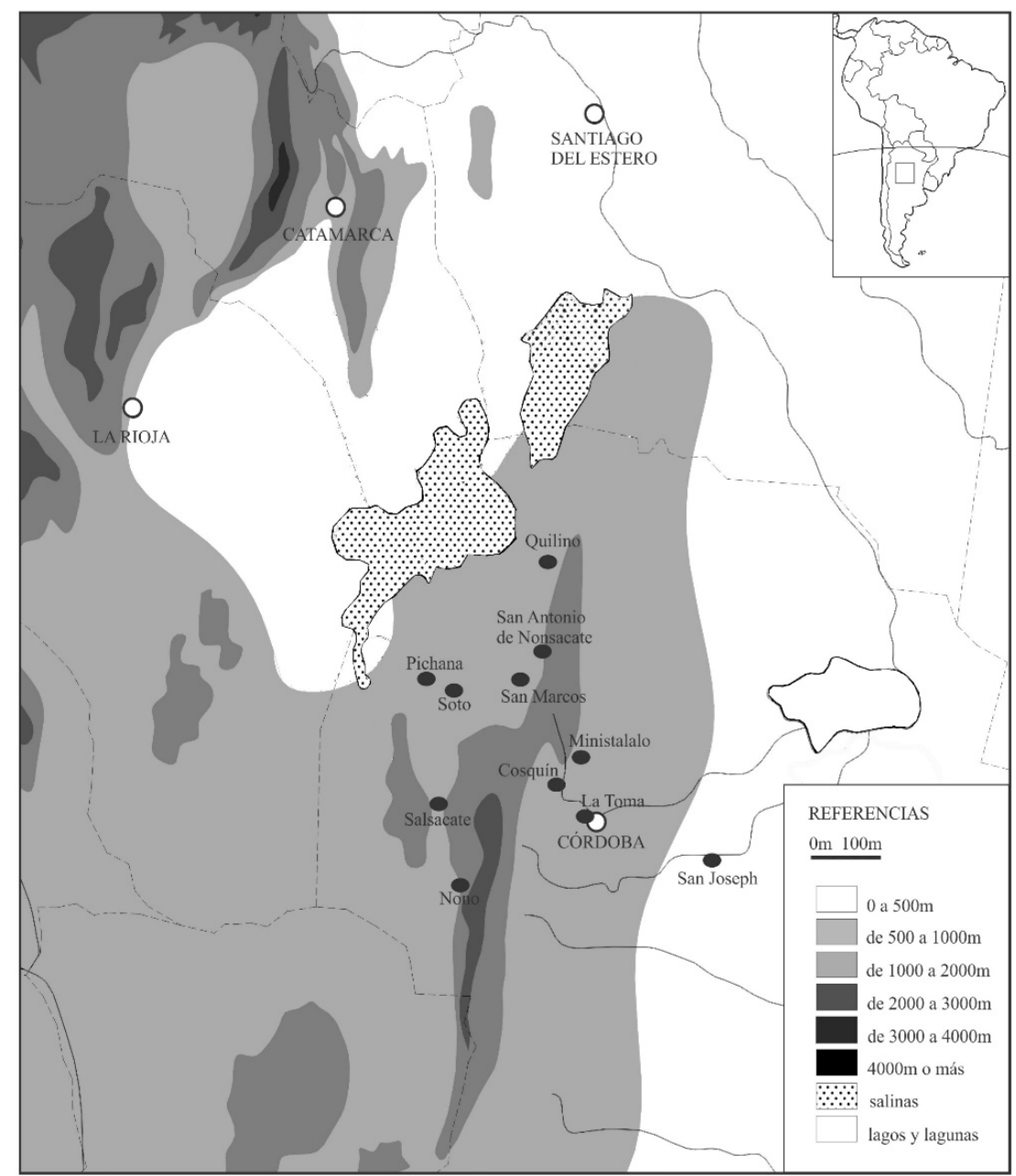

Figura 1. Localización aproximada de los pueblos de indios de Córdoba en la segunda mitad del siglo XVIII ${ }^{21}$.

21 Fuente: Mapa original e inédito de la arquitecta Nuria Cervantes, modificado por la autora. 


\section{Formas de acceso y atribuciones de curacas y cabildos indígenas}

Durante el período colonial el escalón inferior del gobierno de la "república de indios" en Córdoba, como en el conjunto de las colonias, debía recaer en el curaca o cacique y en los alcaldes y regidores del cabildo indígena, con apoyo de otras autoridades encargadas de velar por el acomodo de los indios a la "vida política y cristiana" según la entendían los españoles.

El oidor Francisco de Alfaro, quien delineó en sus Ordenanzas de 1612 para la Gobernación del Tucumán la forma que debían tomar las reducciones de indios, recuperando elementos del modelo toledano, dispuso que el gobierno de estos pueblos estuviera "a cargo de los alcaldes y regidores de indios en cuanto a lo universal, dejando a los caciques el repartimiento de mitas y respeto que se les ha de tener" (ordenanza 72) ${ }^{22}$. En cada pueblo debía haber un alcalde de la misma reducción. Si el pueblo llegaba a 40 casas debía haber un alcalde y un regidor; si pasaba de 80 casas, debían elegirse dos alcaldes y de dos a cuatro regidores (ordenanza 22). Los alcaldes indios recibieron algunas atribuciones judiciales y de policía: se les encomendó cuidar que no hubiera desórdenes entre los indios (ordenanza 22) y se les dio jurisdicción para tener en prisión uno o dos días al que faltara a la doctrina o se emborrachara, o para castigar, por mano de otro indio, delitos que merecieran hasta seis u ocho azotes. En casos más graves debían prender al indio y entregarlo a la justicia en la ciudad (ordenanza 23). Otras tareas de los alcaldes y regidores incluían mantener el orden entre los indios al momento de la siembra, el arado, la cosecha y la recolección de la algarroba por ser el tiempo de mayores borracheras (ordenanza $24^{23}$ ) y castigar a quienes portaran armas (ordenanza 83).

En cuanto al gobierno económico, la ejecución de mitas y cobranza de tasas quedaba a cargo del justicia mayor, o de los alcaldes ordinarios de cada pueblo de españoles en caso que el primero no fuese a visitar los pueblos de indios (ordenanza 73) ${ }^{24}$.

Por otra parte, Alfaro dispuso que se nombrara un fiscal en cada pueblo que pasare de veinte indios y dos en pueblos con más de cien indios. Los fiscales se elegían entre los propios indígenas, debían tener más de 50 años y no pasar de 60 y ser escogidos entre "los que mas bien supieren rezar". Su tarea era "juntar a la doctrina" y en virtud de ello quedaban reservados de todo servicio que les correspondiera por su edad (ordenanza 69).

En los "pueblos de españoles" donde se hicieren reducciones, el oidor previó la elección de alcaldes y demás oficiales indios (ordenanza 78); quedaba a cargo del cabildo español nombrar a un "indio principal" por "alcalde mayor" para el gobierno de los indígenas, en particular los de mita (ordenanza 79). En la ciudad de Córdoba, entre 1613 y 1647 fueron elegidos periódicamente estos alcaldes mayores indios, para ejercer algunas funciones de policía sobre indígenas, "negros y negras"

22 Carta del Licenciado don Francisco de Alfaro, Oidor de la Real Audiencia de la Plata a Su Magestad. Tucumán, 23-I-1612. Archivo General de Indias [España] (en adelante AGI), Charcas, 19, R. 1, No 3. Transcripta en Levi1lier, 1918: 302-303.

23 Estos preceptos se fijaron para todo el territorio americano pocos años después, por cédula de Felipe III. Véase Recopilacion, Libro VI, Título III, Ley XVI: Que los Alcaldes de las Reducciones tengan la jurisdicion, que se declara (Felipe III, 10-X-1618).

24 Cabe aclarar que en la Gobernación del Tucumán el tributo "fue fijado como una carga individual que se calculaba por cabeza y no se asumía colectivamente" y su recaudación corrió a cargo del encomendero durante la prolongada vigencia de la encomienda de servicio personal, esto es, hasta principios del siglo XVIII. Ferrero, 2017: 101. 
y "el demas servicio de los españoles", tales como castigar las borracheras, prender a quienes cometieren delitos dando aviso a la justicia de la ciudad y velar porque esta población de servicio acudiese a la doctrina ${ }^{25}$.

Por último, debemos tener en cuenta que las Leyes de Indias concedieron a los alcaldes indígenas algunas atribuciones sobre la población foránea. Una cédula de Felipe II incorporada en la Recopilación autorizó, en los pueblos donde hubiere alcaldes ordinarios indios y estuviere ausente el corregidor y alcalde mayor o su teniente, que los primeros pudieran prender a "negros" y "mestizos" que hicieren agravios o molestias, y detenerlos en la cárcel hasta que aquellas autoridades llegaran ${ }^{26}$.

Sobre el proceso de nombramiento o elección -según correspondiere- y confirmación de las autoridades, no contamos con estudios sistemáticos que nos permitan seguir su evolución de manera completa. Sabemos que la ordenanza 77 de Alfaro dispuso que los alcaldes indios fueran elegidos cada año por los salientes, en presencia del cura; la asistencia de esta autoridad eclesiástica fue reafirmada en una cédula de $1618^{27}$. Una referencia documental de 1766 indica que el gobernador Fernández Campero habría interrumpido, por una orden de ese año, esa antigua costumbre de que fuesen los curas quienes confirmasen a los nuevos alcaldes en sus cargos. En cambio, delegó esta facultad en el lugarteniente, "otra persona de su confirmación" o en su defecto el cabildo, dada la dificultad de que los indios pudieran trasladarse hasta Salta (capital de la gobernación) para su confirmación por el gobernador. En su fundamento, señaló haber reconocido que en la jurisdicción de Córdoba, en los pueblos de indios de Soto y Pichana, "los alcaldes que eligen por año nuevo, los confirman los respectivos curas, con usurpacion de la real jurisdizion y transgresion de las leyes" y dispuso en consecuencia anular las confirmaciones de alcaldes que hicieren los sacerdotes en lo sucesivo "y a los indios electos que en virtud de ella administraren justicia, por suspensos de las baras, y dos años de destierro" a los fuertes fronterizos del Tío y Punta del Sauce ${ }^{28}$.

La Real Ordenanza de Intendentes dictada para el Río de la Plata en 1782 (en adelante ROI $)^{29}$ mantuvo la renovación anual de alcaldes indios presidida por un juez español, con cargo de dar cuenta al subdelegado o alcaldes ordinarios con informe al intendente para que las aprobara o reformara. Los alcaldes debían ser elegidos entre los propios "naturales" y se prefería a los candidatos que hablaran castellano y fuesen más aplicados a la agricultura o industria (artículo 10). Según este artículo, la recaudación corría a manos de caciques gobernadores, de otros naturales nombrados como cobradores por los intendentes o subdelegados o, en su defecto, de los alcaldes indios. En Córdoba, según ha destacado Ferrero, se sostuvo para tal fin a los capitanes recaudadores de tributo, cobradores españoles que a veces ejercían simultánea-

25 González, 2009: 96. Esta autora también consigna la elección periódica de alguaciles indios entre 1617 y 1638 y la presencia de fiscales indios entre 1616 y 1620. En las fuentes de la segunda mitad del siglo XVII que relevó no halla más indicios de la continuidad de alcaldes mayores, alguaciles y fiscales. Tampoco los encontramos en la documentación del siglo XVIII que revisamos hasta ahora.

26 Recopilacion, Libro VI, Título III, Ley XVII: Que los Alcaldes Indios puedan prender à Negros, y Mestizos, hasta que llegue la justicia ordinaria (Felipe II, 11-VIII-1563).

27 Ibídem, Libro VI, Título III, Ley XV: Que en las Reducciones haya Alcaldes, y Regidores Indios (Felipe III, 10-X-1618).

28 Nota del gobernador Fernández Campero al cabildo de Córdoba. Salta, 15-XII-1766. Archivo Histórico de la Provincia de Córdoba [Argentina] (en adelante AHPC), Gobierno, caja 4, carpeta 5, expediente 90, f. 610 r-v.

29 Real Ordenanza para el establecimiento é instrucción de intendentes de exército y provincia en el virreinato de Buenos Aires. El Pardo, 28-I-1782. Transcripta en San Martino de Dromi, 1994: 127-436. 
mente (o habían ejercido) otros cargos como el de juez pedáneo ${ }^{30}$. Para entonces, si bien la mayoría de los pueblos de indios había retrovertido a la corona y pasado a tributar directamente a las reales cajas -lo que motivó que las atribuciones de curacas y alcaldes se ampliaran, para incluir la recolección del tributo y la participación en la confección de padrones de tributarios- todavía subsistían algunas encomiendas privadas en la Gobernación del Tucumán ${ }^{31}$.

Las actas de elecciones de alcaldes indios de principios del siglo XIX corroboran que estos eran renovados en elecciones anuales convocadas y presididas por el capitán recaudador de tributo, en las que participaban el curaca, el alcalde saliente y los "indios mas antiguos y de edad probecta que asistieron en calidad de regidores" 32 . Los elegidos eran confirmados por los alcaldes ordinarios del cabildo de Córdoba y/o por el gobernador intendente, quien remitía a su vez los acuerdos al virrey, este daba su aprobación y ordenaba que se tomara juramento y fueran puestos en posesión de los empleos. Hasta el momento, no hallamos mayores precisiones en la documentación del siglo XVIII sobre la forma en que los regidores accedían al cargo.

En el caso de los curacas, pudimos identificar tanto herederos de sangre como caciques interinos. Todavía no contamos con datos suficientes para discernir cuál de estas situaciones era predominante, pero en cualquier caso debían ser confirmados por el gobernador intendente, de acuerdo con la $\mathrm{ROI}^{33}$. En los casos en que no existían candidatos con antecedentes hereditarios posibles de confirmar, el propio gobernador intendente los nombraba y a veces pedía al capitán recaudador que propusiera el individuo más apto para el empleo ${ }^{34}$. Por su parte, el recaudador podía llegar a pedir remoción del curaca si consideraba que no cumplía con los deberes del cargo ${ }^{35}$.

En algunos de los pliegos de nombramiento de caciques se les atribuyeron funciones que podrían entenderse como judiciales y de policía, tales como gobernar y

30 La figura del capitán recaudador de tributo y su relación con los cambios en la administración del ramo en el siglo XVIII, aguardan un estudio específico. Localizamos menciones de su designación en las actas del cabildo de Córdoba en las décadas de 1760 de 1770, aunque no descartamos que existieran en años previos. El cabildo les asignaba el cobro de la tasa y la confección de los padrones en uno o más pueblos de indios o en el territorio de uno o más "partidos" (excepcionalmente, había dos cobradores por partido si este era muy grande); en algunas actas también figura el nombramiento de un agente similar para la ciudad. En las fuentes posteriores a la implementación de la ROI, los capitanes recaudadores aparecen nombrados por el gobernador intendente a propuesta de los alcaldes ordinarios a cargo del ramo, con jurisdicción sobre uno o más pueblos de indios y por el tiempo que el gobierno tuviere por conveniente. Actas capitulares del 16-VI-1761 y 17-IX-1778. Archivo de la Municipalidad de Córdoba, Argentina, Actas Capitulares, tomos 31 y 36 (agradezco estas referencias a Ana Inés Punta). Título del receptor de Nono y Salsacate. Córdoba, 16-III-1786. Fondo Documental Monseñor Pablo Cabrera, Universidad Nacional de Córdoba [Argentina] (en adelante FDPC), Documento 9370. Para más información sobre la administración del ramo de tributo en Córdoba, ver Ferrero, 2017.

31 Ferrero, 2017.

32 Acuerdos de elecciones de oficios concejiles de los pueblos de indios de Córdoba. Córdoba, 16-I-1802. Archivo General de la Nación [Argentina] (en adelante AGN), Sala IX, legajo 30-7-1, f. 1r. Acuerdo de elecciones de oficios concejiles de los pueblos de indios de Córdoba. Córdoba, 15-I-1803. AGN, Sala IX, legajo 30-7-2. Acuerdo de elección de alcalde de los pueblos de Soto y Quilino. Córdoba, 7-I-1809 y 28-I-1809. AHPC, Escribanía 4, legajo 38, expedientes 24 y 25 .

33 Estos procedimientos se observan sobre todo cuando los caciques renunciaban a su cargo. Ver, por ejemplo, la renuncia del curaca interino de Soto. Córdoba, 27-X-1809. AHPC, Escribanía 4, legajo 37, expediente 10.

34 Nota del gobernador intendente Sobremonte al cabildo de Córdoba, sobre nombramiento de cacique interino de Nono. Córdoba, 19-V-1797. FDPC, Documento 5991.

35 Presentación del capitán recaudador Agustín de Osan al cabildo de Córdoba, pidiendo la destitución del curaca de Quilino por apropiarse del tributo recaudado. Córdoba, 28-III-1810. AHPC, Escribanía 4, legajo 39, expediente 16 . 
corregir las "faltas y excesos de los indios a su cargo"36. En los pleitos criminales contra caciques por "excesos de jurisdicción" se corrobora el ejercicio de este tipo de funciones, que era compartida con los alcaldes indios, y era motivo de incriminación a los curacas cuando no ejercían la vigilancia y castigo de los sujetos de sus comunidades. También curacas y alcaldes recibían las querellas de los vecinos contra los indios, directamente o por intermediación de autoridades españolas, como se observa en el caso de Salsacate que trataremos más adelante, cuyo alcalde atestiguó recibir diariamente querellas de los vecinos por supuestos robos de ganado de los habitantes del pueblo ${ }^{37}$.

\section{Competencias de alcaldes de la Hermandad, jueces pedáneos y sus auxiliares en pueblos de indios}

El contenido de los conflictos que trataremos nos invita a repasar las competencias de las autoridades que tenían atribuciones de gobierno, justicia y policía en la república de "españoles" y además intervenían en causas de indios.

De acuerdo con la Recopilación, eran los virreyes quienes podían conocer en primera instancia en los pleitos "que en qualquiera forma se ofrecieren entre los Indios, y assimismo entre Españoles, en que los Indios fueren reos"; esta facultad se extendió a los gobernadores de las Indias y Filipinas, mientras que las Audiencias actuaban como tribunales de apelación. Los alcaldes ordinarios podían conocer en primera instancia en pleitos de indios con españoles "y determinarlos definitivamente, donde estuviere en costumbre"; en cambio, Provinciales y Alcaldes de la Hermandad tenían prohibido conocer en pleitos de indios "en mas que hazer la averiguacion, y remitirla al ordinario, si no fuere sobre hurtos de ganados, que en este caso podran proceder como los ordinarios" $" 38$.

En lo que respecta a las justicias españolas, en Córdoba como en todo el espacio colonial, concurrían y muchas veces se superponían, las competencias de los oficios regios y capitulares. En el cabildo español, llevaban la vara de justicia los alcaldes ordinarios, quienes "eran los jueces naturales para el fuero común, con independencia de que sobre el mismo término actuasen otros oficios con jurisdicción de origen real" y "tenían capacidad para conocer y sentenciar todas las causas civiles y criminales ocurridas en su término siempre que no correspondiesen a algún fuero de excepción" 39 . A ellos se sumaban los alcaldes de la hermandad-oficio que empezó

36 Informe del teniente de gobernador intendente a este último, sobre nombramiento de cacique de Ministalalo. Córdoba, 4-VIII-1784. FDPC, Documento 9186, f. 1r-v. En la Recopilación, la jurisdicción de los caciques era definida negativamente, indicándose que no tendrían jurisdicción criminal sobre casos de muerte, mutilación de miembro y castigo atroz. Recopilación, Libro VI, Título VII, Ley XIII: Que declara la jurisdicion de los caciques (Carlos V, 17-XII-1551; Felipe II, 09-XII-1558).

37 Carta del alcalde de Salsacate al protector de naturales. Sin aclaración de lugar y fecha. AHPC, Escribanía 3, legajo 38, expediente 6, ff. 13r-14r.

38 Recopilación, Libro III, Título III, Ley LXV: Que los Virreyes conozcan en primera instancia de causas de Indios, con apelacion à sus Audiencias (Felipe II, 09-IV-1591). Libro V, Título III, Ley XVI: Que los alcaldes ordinarios puedan conocer en primera instancia de pleitos de Indios con Españoles (Felipe II, 12-I-1561). Libro V, Título IV, Ley III: Que los Ministros de la Hermandad procedan con los Indios, conforme a esta Ley (Felipe II, 21-IX-1591). Libro V, Título X, Ley XIII: Que la facultad dada à los Virreyes para conocer en primera instancia en causas de Indios, se entienda con los demàs Governadores de las Indias (Felipe II, 19-IV-1591; Felipe III, 12-XII-1619).

39 Agüero, 2008: 68 y 77. 
a nombrarse a fines del siglo XVI y cuyo número se mantuvo en dos desde el siglo XVII- que tenían jurisdicción especial sobre el área rural de la jurisdicción del cabildo y eran elegidos anualmente por este cuerpo, mientras que el alcalde provincial de la hermandad era un cargo venal y perpetuo. Alcaldes y provinciales de la hermandad entendían en los llamados "casos de Hermandad", esto es, "en hechos delictivos ocurridos en descampados, caminos y poblados sin Alcalde". Durante el siglo XVIII y hasta 1770 -año en que fueron suprimidas por el cabildo- estas justicias contaron con cuadrilleros, auxiliares designados por el provincial de la hermandad que salían al campo a hacer persecuciones y $\operatorname{arrestos}^{40}$.

En el siglo XVIII, particularmente después de la división de la Gobernación del Tucumán en dos intendencias en 1782, la red de oficios en la campaña creció y se complejizó. Los alcaldes de la hermandad se mantuvieron, aunque con competencias restringidas ${ }^{41}$. A ellos se sumaron los jueces pedáneos, oficios de comisión de la jurisdicción del cabildo cuyas funciones fueron resignificadas en beneficio del poder regio al instalarse el primer gobernador intendente en Córdoba en 1785. Como señalamos en un trabajo anterior, estos jueces - previamente nombrados por el cabildo - quedaron como delegados nombrados por el intendente con jurisdicción sobre un distrito de campaña llamado pedanía, cuyos límites fueron acotados y precisados. Desde entonces, esta red de jueces de campaña se expandió notablemente y sus distritos se multiplicaron, reduciéndose en superficie pero aumentando en la cantidad de población que albergaban, al compás del crecimiento demográfico, un aumento similar al documentado en muchas otras regiones hispanoamericanas ${ }^{42}$.

Los jueces pedáneos tenían atribuciones de policía y delegación para juzgar en causas leves (esto es, en casos civiles de bajo monto y en casos criminales sin derramamiento de sangre), mientras que en casos más importantes iniciaban el proceso de judicialización mediante una sumaria información antes de remitir a los reos al gobernador intendente o a los alcaldes ordinarios; también podían actuar como mediadores cuando las partes quisieran llegar a un acuerdo sin pasar por la instancia de judicialización ${ }^{43}$. Contaban con la posibilidad de ser auxiliados por celadores (auxiliares con funciones de policía) o milicianos para llevar adelante sus procedimientos y podían iniciar causas de oficio, sin mediar querella o denuncia de un hecho por un vecino u otra autoridad ${ }^{44}$.

Para ser elegible como juez pedáneo, un vecino debía cumplir con los requisitos de ser honrado y de buena fama, alfabeto y estar afincado en la jurisdicción. Tal como se verifica en otros espacios hispanoamericanos, quienes detentaban estos empleos en Córdoba eran vecinos "notables", propietarios de estancias o haciendas, que ejercían simultáneamente o en el curso de su vida los roles de jueces, comandantes de tropas veteranas o de milicias, recaudadores de tributo o de diezmos. Eran designados para gobernar y vigilar los mismos distritos de donde procedían o en los que residían, por consiguiente tenían un denso tejido preexistente de relaciones con la población sujeta a su autoridad. Desde la creación de la intendencia, sus atribuciones se reforzaron así en los reglamentos como en la práctica ${ }^{45}$.

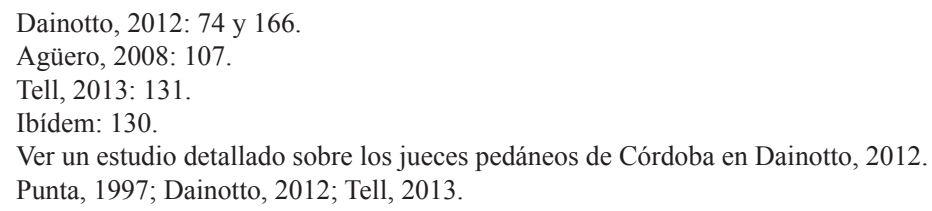


Sobre las disposiciones dictadas para esta región en lo referido a las competencias de las justicias españolas -ordinarias y delegadas- en causas de indios, contamos con información parcial, dada la falta de estudios ya señalada. En sus Ordenanzas para la Gobernación de Tucumán de 1612, el oidor Alfaro determinó que los alcaldes de la hermandad solo podían conocer en causas de indios cuando estos hubiesen cometido homicidio, robo de mujer, hurto de ganado mayor, o herido a otra persona para robar. Estas competencias se ampliaban significativamente si previamente el alcalde de la hermandad había sido alcalde ordinario en el mismo distrito, en cuyo caso podía proceder contra los indios en causas de hermandad e incluso recibir comisión para otros casos que no fueran de hermandad (ordenanza 74). Complementariamente y con el objeto de prevenir agravios a la población indígena, la ordenanza 75 dispuso que la justicia mayor u ordinaria y los alcaldes de la hermandad en los casos precedentes llevaran al indio a la cárcel de la ciudad o pueblo de españoles para sentenciarlo y ejecutar la sentencia. Las tareas de vigilancia de estas autoridades incluían castigar a aquellos indios que portaran armas y prevenir las borracheras.

Según se consigna en investigaciones de historia del derecho, a raíz de los excesos cometidos por los alcaldes de la hermandad, en 1620 el teniente de gobernador de Córdoba prohibió a los alcaldes de la hermandad la entrada a los pueblos de indios sin su licencia y se reservó el conocimiento de todas las causas de indios, prohibición que fue reiterada en 1628 por el gobernador del Tucumán para todo su distrito ${ }^{46}$. Inferimos que, desde entonces, el gobernador y sus tenientes y a partir de la implementación de la ROI en 1785 el gobernador intendente de Córdoba y su teniente asesor letrado, más los alcaldes ordinarios en causas de españoles contra indios, fueron las únicas autoridades españolas con jurisdicción civil y criminal en los pueblos de indios a nivel de esos distritos, aparte del virrey y la audiencia ${ }^{47}$.

En líneas generales, lo antes expuesto se verifica en las trece causas criminales de indios contra españoles -o viceversa- que localizamos hasta ahora para la segunda mitad del siglo XVIII en la jurisdicción de Córdoba ${ }^{48}$. Las tres que se desarrollaron con anterioridad a la ROI fueron iniciadas ante los alcaldes ordinarios cuando involucraron a españoles (como demandantes o acusados). Cuando la demanda corrió a cargo de un cacique, se hizo directamente ante la Audiencia de La Plata o ante el alcalde ordinario si el gobernador no estaba en la ciudad, pero con pedido que se diera cuenta a este de todo lo actuado. De las causas iniciadas después de la sanción de la ROI, solo una se presentó ante un oficial de real hacienda (en el caso de Salsacate

46 Zorraquín, 1952: 72-73.

47 En la Gobernación del Tucumán no hubo corregidores de indios. El gobernador Alonso de Ribera quiso nombrar corregidores para Santiago del Estero que fueron rechazados por el Cabildo y luego nombró "tenientes de naturales" para Santiago del Estero, La Rioja, Córdoba, Catamarca y San Miguel de Tucumán con funciones similares. En Córdoba estos tenientes fueron designados en 1606-1607, con vara alta de justicia -incluyendo conocimiento de cualquier causa civil o criminal que involucrara indios, encomenderos y "pobleros" (administradores de los encomenderos en los pueblos de indios)- y con "orden de visitar la tierra, desagraviar a los indios y castigar los abusos ejecutando la legislación vigente" en el "partido de pueblos de indios" que les fuere asignado. El gobernador contó con el apoyo de la Compañía de Jesús, pero la oposición de los cabildos de españoles ante la Audiencia de Charcas - con la adhesión de la orden de La Merced- frustró el proyecto, puesto que lograron que la Audiencia suspendiera las visitas recién iniciadas en dichas jurisdicciones y anulara las proyectadas para Salta, Jujuy, Esteco y Madrid de las Juntas. Carmignani, 2015: 23-24 y 29.

48 No consideramos en este punto las causas civiles tramitadas en estos años, porque se refieren a los derechos de tierras y aguas de los pueblos y no corresponden al tipo de delitos o contravenciones que caían bajo jurisdicción de un juez pedáneo o alcalde de la hermandad; en parte, esto puede deberse a que podían resolver muchos de esos conflictos mediante juicio verbal. 
que tratamos más adelante) y las ocho restantes se iniciaron ante el gobernador intendente (o en su ausencia, ante su teniente asesor), quien entendió directamente en algunos casos y en otros decidió pasar la causa a su teniente asesor o a un alcalde ordinario - cuando la causa involucró españoles- quien, no obstante, dictó fallo con parecer del asesor letrado.

Debemos agregar que, en reemplazo de corregidores o tenientes de gobernador, la ROI dispuso que el intendente nombrara un subdelegado en las cuatro causas -español- en los pueblos de indios que fueran cabeceras de partido, para mantener a los naturales "en buen órden, obediencia y civilidad" (artículo 9). Los alcaldes ordinarios y los subdelegados donde los había ${ }^{49}$ quedaron, además, a cargo de la cobranza y conducción del tributo (como carga de oficio) y de dar cuenta de las elecciones de alcaldes indígenas a los alcaldes ordinarios o subdelegados, con informe al intendente (artículos 10 y 116).

En cuanto a los jueces pedáneos, no se incluyeron artículos específicos en la ROI, sino en los pliegos de nombramiento y disposiciones locales. Atendiendo a las instrucciones contenidas en esos papeles, entendemos que su jurisdicción no alcanzaba explícitamente al territorio y sujetos de los pueblos de indios ${ }^{50}$. En los expedientes criminales consultados, observamos que estos jueces daban parte de las faltas de los indios al alcalde indígena para que este resolviera y solo intervenían directamente en dos situaciones: cuando encontraban a los habitantes de los pueblos fuera de ellos -en caminos o campos- cometiendo presuntos delitos, en cuyo caso podían arrestarlos y ponerlos a disposición del gobernador o del intendente, o cuando este último les ordenaba conducir un reo desde el pueblo a la cárcel de la ciudad o realizar otra comisión específica, es decir, cuando los pedáneos actuaban como comisionados o jueces de comisión ${ }^{51}$. Las comisiones incluían habitualmente diligencias tales como levantar una sumaria información y tomar declaraciones; en casos excepcionales se les cometía otro tipo de tareas como las de reunir y empadronar indios de pueblos pequeños que se hubiera decidido agregar a otros.

En los casos más prolijamente registrados, advertimos que el juez de comisión primero se presentaba ante el curaca y/o el cabildo de indios para que aceptaran su actuación. Así lo hizo en 1808 el comandante Josef Anselmo Moyano, comisionado por el gobernador intendente para separar del cargo al cacique de Quilino y "pasar el cacicazgo" a un reemplazante. La comisión también incluía supervisar que curaca y alcaldes demolieran los puestos que -según se decía- servían de refugio a indios ladrones. Luego, el intendente ordenó al "juez celador” Juan Manuel Ramallo que pasara a Quilino, "tomando el auxilio que nececite de los cabos militares mas inme-

49 Hasta el momento, no nos consta que se haya nombrado en Córdoba un subdelegado con jurisdicción en los pueblos de indios o se haya dado esa función a otra autoridad.

50 Disposiciones del gobernador intendente Sobremonte sobre jueces pedáneos. Córdoba, 29-I-1785. FDPC, Documento 4032. Transcripto en Punta, 1997: 273-275.

51 En la documentación revisada encontramos dos usos de los términos "comisionado" o "juez de comisión". En ocasiones, se usa juez de comisión como sinónimo de juez pedáneo, apuntando a su condición genérica de juez delegado de la justicia ordinaria. En los casos que analizaremos, la denominación se ajusta a una segunda definición: aquel juez "designado ocasionalmente para cumplir una misión específica” (Barriera, 2012: 9), cuyo mandato duraba "hasta que quien lo había designado diera por satisfecha su pretensión" y no tenía otro límite geográfico que el de su juez ordinario, "pues todos los hechos conexos con el principal eran de su competencia, en cualquier partido o jurisdicción territorial que acontecieran" (Dainotto, 2012: 157). Los comisionados podían recibir facultades judiciales, de gobierno o administrativas. Sobre esta figura, ver los estudios de Storni, 1997a y $1997 b$. 
diatos", prendiera con cautela al alcalde del pueblo y a otros indios "inobedientes", los condujera a la cárcel de la ciudad, sin perjuicio que el comisionado Moyano cumpliera las órdenes del gobierno que ya tenía ${ }^{52}$.

En qué circunstancias podía considerarse a este tipo de procedimientos de los comisionados como encuadrados dentro de la ley -cuando no mediaba una providencia escrita del gobernador o del intendente- era una cuestión que las autoridades indígenas y los protectores de naturales disputaron ásperamente con los alcaldes de la hermandad y sus cuadrilleros, con los jueces pedáneos y sus celadores, sobre todo porque estos incursionaron asiduamente en el territorio de los pueblos para intervenir directamente en sus asuntos en la segunda mitad del siglo XVIII. Así, los alcaldes indígenas tuvieron que defender su jurisdicción y los curacas sus títulos con apoyo de las comunidades.

\section{Conflictos de jurisdicción en los pueblos de indios (1750-1810)}

Las competencias o contiendas de jurisdicción, según se ha señalado en numerosas investigaciones, cumplieron un rol destacado en la vida política colonial y podemos considerarla una parte inherente del funcionamiento del gobierno colonial, dada la relativa fragmentación y superposición de potestades y jurisdicciones ordinarias y delegadas ejercidas por autoridades de diverso rango, cada una con sus propios intereses y redes de alianzas y enfrentamientos. Para Córdoba específicamente, Dainotto plantea que la extensión de la red de judicialización en la segunda mitad del siglo XVIII produjo abundantes contiendas de este tipo entre las autoridades españolas o criollas, "pujas entre funcionarios por imponer cada uno su derecho a resolver un caso" y "determinar quién era el 'juez natural' de la causa, entre jueces de diversa procedencia que se creían con derecho a entender en una misma causa", por ejemplo, alcaldes de la hermandad, jueces pedáneos, oficiales militares e incluso eclesiásticos ${ }^{53}$. Una de las tácticas políticas incorporadas por los indígenas y por otros grupos subalternos en el mundo colonial consistió, precisamente, en sacar provecho de estas competencias jurisdiccionales, manipular rivalidades políticas entre funcionarios locales o de distinto rango ${ }^{54}$.

Las competencias jurisdiccionales que se dirimieron en las causas criminales sobre pueblos de indios de Córdoba tramitadas entre 1750 y 1810, tuvieron origen fundamentalmente en la intrusión de las autoridades españolas en la jurisdicción de las autoridades indígenas -es decir, en su territorio y sobre sus sujetos-, por lo que representaron una seria amenaza para la autonomía de gobierno y los derechos de tierras y acceso a recursos de esas comunidades. Los dos casos mejor documentados ocurrieron en los pueblos de San Antonio de Nonsacate (partido de Ischilín) en 1778 y Salsacate (partido de Traslasierra) en 1782, que en esa época se contaban entre los de menor población y los más agresivamente asediados por propietarios de las cercanías ${ }^{55}$.

52 Informe del juez comisionado al gobernador intendente. Quilino, 20-II-1808. AHPC, Escribanía 4, legajo 33 tomo II, expediente 6, ff. 169r y $174 \mathrm{r}$.

53 Dainotto, 2012: 192.

54 De esta táctica dan cuenta mucho de los estudios citados en la introducción y también era una práctica incorporada en el juego político de los colonos y vecinos.

55 En la revisita de 1785 se empadronaron 50 habitantes en San Antonio y 60 en Salsacate. Los demás pueblos tenían entre 93 y 547 habitantes registrados. Ferrero, 2017: 55. 
En San Antonio de Nonsacate, el "cacique originario" Antonio Melo demandó al cuadrillero de la hermandad Ramón Cáceres por desalojar a siete familias del pueblo, quemar los ranchos de algunas y demoler los de otras, derribando los cueros y palos con los que estaban construidos. Se presentó ante el alcalde ordinario de segundo voto por estar el gobernador ausente de la ciudad, pero bajo la condición de dar cuenta de sus actuaciones a este último, solicitada expresamente por el protector de naturales.

Como argumento central, el cacique esgrimió que "no recide en su ministerio de quadrillero jurisdicion alguna" y que si los indios del pueblo hubieran cometido delitos podían ser punidos pero no despojados de sus tierras ${ }^{56}$. Cáceres era yerno de Manuela Olmos, hija del difunto Joseph Clemente de Olmos y Aguilera, a su vez descendiente de una vieja familia de vecinos feudatarios. Eran propietarios de tierras colindantes con San Antonio y arrastraban contiendas de larga data por intentos de apropiación de terrenos de los indios ${ }^{57}$. El título de cuadrillero de Cáceres había sido expedido por el alcalde provincial de la santa hermandad. Además Cáceres era (o había sido) recaudador de tributos, a cargo de empadronar a los indios de San Antonio, con instrucción de distinguir a los "foráneos" de los "legítimos"; en ese ejercicio se hacía acompañar con soldados para exigir el pago de la tasa a los tributarios -si era necesario con violencia- sin mediar presencia del curaca.

En su réplica, el cuadrillero enfatizó que el pueblo, en rigor, solamente tenía seis indios naturales contando el cacique y que los desalojados eran agregados (foráneos) dedicados al hurto y al vicio, "que contra todo derecho ha introducido el casique o mandon" y "que se dan al pueblo por tributarios, a fin de no ser lanzados y estar continuando su desarreglada vida". En concreto, se trataba de seis individuos a los que calificó de "mestizos", "mulatos" y solo a uno de ellos de "indio", varios de los cuales habían sido criados o agregados en las estancias de su suegro u otros vecinos prominentes del partido ${ }^{58}$. Cáceres adujo tener una orden del alcalde provincial para expulsar a estos agregados y hacerlos "conchabar" por vecinos honrados dueños de tierras; del curaca Melo en particular dijo que se había ausentado cuatro años por mudarse con su manceba al distante pueblo de indios de La Toma y por ello los excesos de los habitantes del pueblo no tenían contención. Mencionó también que el desalojo se daba en cumplimiento de una provisión de la real audiencia de 1770 donde presuntamente se dispuso que estos agregados fuesen despojados y expulsados con sus haciendas y familias a diez leguas de distancia y a costa de sus propios bienes, además de amenazar al cacique con la pena de pérdida del cacicazgo y destierro,

56 Presentación del cacique ante el alcalde ordinario de segundo voto. Córdoba, 6-XI-1778. AHPC, Escribanía 2, legajo 58, expediente 5, f. $1 \mathrm{r}$.

57 Según el protector, Joseph de Olmos y Aguilera los había reducido a la mísera extensión de un cuarto de legua a todos los vientos; el cuadrillero admitió que esas tierras eran "un puro churchal, sin pastos ni aguas". La revisita de 1785 corrobora su descripción. Córdoba, 02-IX-1779. AHPC, Escribanía 2, legajo 58, expediente 5, f. 27v. San Antonio de Nonsacate, 03-IX-1785. AGN, Sala IX, Documentos Diversos, legajo 31, f. 79r.

58 El término "agregado" aparece profusamente en los documentos de la Gobernación del Tucumán en el siglo XVIII y su uso encubre una variedad de situaciones: principalmente individuos o familias que se integraban como miembros a las unidades domésticas campesinas de forma permanente o en determinados momentos de su ciclo vital, o bien se instalaban en tierras de unidades productivas de mayor envergadura a cuyo propietario entregaban periódicamente renta en trabajo. En ambos casos, el uso del término subrayaba su condición de gente sin tierras propias (Tell, 2008, cap. 5). También solía denominarse así a los foráneos incorporados en pueblos de indios, aunque en la documentación que consultamos se trasunta que este no era el término usado por la propia comunidad receptora, sino por autoridades y vecinos externos. Sobre agregados en pueblos de indios ver Farberman, 2009. 
en caso de volver a tener un conflicto con el maestre de campo don Joseph Clemente de Olmos y Aguilera (el suegro de Cáceres) o sus descendientes ${ }^{59}$. Finalmente, se resguardó en las ordenanzas del virrey Toledo -"por ser municipales"- que fijaban pena al cacique que admitiera indios de otro pueblo ${ }^{60}$.

Desde luego, el cacique y los propios desalojados planteaban que todos los expulsados eran indios del pueblo casados con indias, a excepción de algún que otro mulato también casado con india del pueblo. El protector de naturales ratificó y amplió los argumentos del cacique, enfatizando que el verdadero interés de Cáceres era apropiarse de una tierra contigua a la suya. Con respecto a las tierras, recalcó que los indios tenían "privilexios y fueros" y que, en tanto pueblos de reducción, contaban con "el derecho del dominio, propriedad y pocesion que logravan mediante la real merzed que se les concedia para su establesimiento". Sobre la cuestión de la jurisdicción, observó que Cáceres se había constituido juez y parte en su propia causa y se había valido de la autoridad de "comicionado quadrillero del alcalde provincial" pese a no residir en él jurisdicción alguna sobre los indios. Sobre esto puntualizó:

la jurisdizion de estos quadrilleros y aun de el alcalde provincial que les nombra, solo se estiende a los cinco caxos de hermandad cuya transgresion por ser de tanta gravedad pide lo primero el arresto o pricion de los que delinquen en ellos, y no haviendo verificado esta con los havitadores de aquel pueblo, que les dexo libres y aun admitio a sus terrenos a los que quisieron pasarse unico indulto que les concedio a los que le dexo sin incendiarles sus abitaciones en constante no presedio causa alguna para el referido hecho ${ }^{61}$.

Sobre la cuestión más específica de la jurisdicción sobre los naturales y foráneos de los pueblos, deslindó con precisión las competencias del cuadrillero y del cacique:

el separar de los pueblos de indios a los agregados que se introduscan toca y pertenece al curaca governador del pueblo, hasiendolo presente a su protector general para el caso de que no intervengan motivos que lo impidan, como es el de estar casados con indias del pueblo, de suerte que aun quando no lo fueran naturales de aquel pueblo los nuebe que han padesido el incendio no le toca ni pertenece a aquel quadrillero hacer esta inbestigacion, y por ello se debe presindir de la presente causa, si son o no indios lexitimos, pues para graduarle el delito cometido sobre el hecho referido es indiferente el que sean de una u otra clase de las que expresa en su escripto $[\ldots]^{62}$.

59 Presentación de Cáceres al cabildo de Córdoba. San Luis de Nodolma, 3-XI-1778. AHPC, Escribanía 2, legajo 58, expediente 5, ff. 3r-4r, 11v-12r. No se insertó traslado de la provisión.

60 Ordenanzas generales para la vida común en los pueblos de indios. Arequipa 6-XI-1575. Biblioteca Nacional del Perú, Manuscrito B. 511, fs. 551r-577v. En particular, citó la ordenanza 23 del título VI, que encomendaba a los "caciques principales" que "reduzcan los indios ausentes a sus pueblos, y no admitan en él ni en su servicio forasteros". Véase la transcripción de Sarabia, 1989, t. II: 245. También hizo referencia a las reiteradas prohibiciones de que negros, zambos y mulatos residieran entre los indios.

${ }^{61}$ Presentación de Ramón de Cáceres al alcalde ordinario de segundo voto. Córdoba, 10-XI-1778. AHPC, Escribanía 2 , legajo 58 , expediente 5 , ff. $5 \mathrm{v}-6 \mathrm{r}$.

62 Ibídem, f. $25 \mathrm{r}-\mathrm{v}$. 
En esta exposición, como puede apreciarse, recalcó que todos los habitantes de los pueblos de indios caían bajo jurisdicción del cacique gobernador, fueran naturales o foráneos. Más tarde, completaría su argumentación con cuestiones de procedimiento, al añadir que aun si se concediera, a título de hipótesis, que el cuadrillero fuese un juez con autoridad competente y hubiera sido facultado por el alcalde provincial, no había intervenido el protector de naturales ni habían mediado las formalidades de derecho, esto es, las "causas y sumarias con su audienzia y sitacion" y la remisión de los reos a la cárcel de la ciudad ${ }^{63}$. Además, ninguno de los vecinos se había querellado con el pueblo en los siete años que este protector ejercía el oficio. De haber ocurrido delitos, continuaba su argumentación, se debió exponer en expediente separado por las partes agraviadas, puesto que en el presente pleito el hecho que se juzgaba era el incendio de los ranchos y no los delitos de los indios.

El protector hacía referencia a una misiva del alcalde provincial de la hermandad Domingo Garay dirigida a Cáceres, que contenía instrucciones sobre las acciones a seguir frente a los robos de los "agregados" de San Antonio. En esta pieza cuyo original se insertó en el expediente y en la que el cuadrillero basó parte su defensa, el provincial distinguía claramente las acciones a seguir según se tratara de indios y agregados y delineaba una economía de castigos a los pobladores de la campaña:

los apremiara severamente castigandolos esto es para con los agregados que no sean indios legitimos del pueblo; y quando alguno aiga echo algun robo conciderable sigale sumaria y remitalo preso a esta ciudad ante mi jusgado pero quando sea lebe de poca monta soba [palabra ilegible] con ellos.

Por lo que mira a los indios legitimos del pueblo a estos les ha de hacer sumaria quando agan alguna maldad y con ella los ha de remitir presos a esta ciudad sin darles castigo alguno... asta que demos cuenta al sr governador en terminos que se hallan todos estos pueblos.

Al dicho Santucho [uno de los desalojados por Cáceres de San Antonio de Nonsacate] si es agregado sobelo bien y metalo en un cuerno[?] si es como vm me dise y sigale sumaria para maior seguro y si es indio del pueblo sigale sumaria y mandelo preso, si no se quiere contener es quanto ocurre $[\ldots]^{64}$.

De este modo, el alcalde provincial dejaba a salvo la jurisdicción de las autoridades indígenas y habilitaba al cuadrillero a castigar a los que no fueran naturales del pueblo. De ahí el afán de Cáceres de distinguir a los habitantes originarios del pueblo (legítimos) de los foráneos (agregados) y en marcar su acatamiento a las órdenes de su superior inmediato. Frente al juez delegado del gobernador que actuó en la última parte del juicio, Cáceres aseguró no haber tenido "interbencion ni mezcla alguna" con los indios naturales del pueblo, pese a estar informado de los delitos de robo y amancebamiento de estos. Se contradijo, no obstante, con su declaración previa ante el alcalde ordinario (juez de la primera parte del pleito), en la que afirmó tener probado que los indios "legítimos" o naturales entraban sin licencia a campos privados a campear, melear y cosechar frutas silvestres, para volverse a sus casas cargados de carne, grasa y cebo para vender. Según esta relación, el cuadrillero ya se había arro-

63 Ibídem, f. 24r-v.

${ }_{64}$ Carta de Domingo Garay a Ramón de Cáceres. Córdoba, 12-X-1778. AHPC, Escribanía 2, legajo 58, expediente 5 , ff. $16 \mathrm{r}-17 \mathrm{r}$. 
gado algunas atribuciones de policía y justicia al amenazarlos con "penas graves", si entraban en "tierras agenas sin permiso de sus dueños" y dar la orden de que cuando matasen alguna res, le llevaran la señal y yerro ${ }^{65}$.

El fallo inicial del alcalde ordinario de segundo voto fue contrario a Cáceres y en esas circunstancias el cuadrillero declinó su jurisdicción, aduciendo que por ser recaudador de tributo nombrado por el teniente de oficiales reales le correspondía juzgarlo al justicia mayor o en su defecto el alcalde de primer voto, y que esperaría la llegada inminente del gobernador a la ciudad de Córdoba para presentarse ante él. Al reconocerse como delegado de la real hacienda, apostaba a que la justicia regia ganara preeminencia sobre la jurisdicción capitular y al esperar la llegada del gobernador, quizá el cuadrillero calculara salir airoso del juego de poder local. No sabemos si esta táctica fue exitosa, puesto que el expediente está incompleto y no figura el fallo del juez delegado, nombrado por el gobernador Andrés Mestre durante su paso por la ciudad.

En el pueblo de indios de Salsacate la intromisión del sargento mayor reformado y juez pedáneo Diego Quevedo, fue más directa y agresiva. La denuncia judicial corrió a cargo de tres indios del pueblo (Prudencio Malla, Faustino y Domingo Ama1la), fue presentada en 1782 ante el teniente de oficial real de la caja sufragánea de Córdoba, debido a que involucraba reclamos de los recaudadores por tributos atrasados y problemas de los indios para conseguir los recibos del pago de la tasa. El expediente continuó su recorrido por la contaduría de la gobernación con sede en Jujuy ${ }^{66}$ cuyos oficiales, a su vez, pasaron la causa al gobernador Mestre por ser a quien correspondía tomar providencia sobre el asunto. Finalmente, el gobernador la remitió a su teniente en Córdoba, cuya sentencia desconocemos por estar trunco el expediente.

Los indios relataron ante el teniente de oficiales reales las reiteradas agresiones de Quevedo contra las autoridades y habitantes del pueblo, enfatizando la ascendencia de curacas y alcaldes. Narraron que en una ocasión había prendido a varios indios y colgado a un alcalde (descendiente legítimo de curacas del pueblo) aunque no llegó a azotarlo porque lo frenó la misma gente del pueblo. En otra, había agredido físicamente al curaca, desconociendo "el titulo, que de tal cacique tenia, y de la lexitimidad con que varios señores governadores se lo havian dado". También había echado fuego a la casa de un alcalde indio "elejido plenamente por todo el pueblo" con el objeto de desalojarlo de tierras que reclamaba como propias; en la misma ocasión, degradó al curaca "y puso en otro el cargo a quien en manera alguna le pertenecia por no tener sangre de curaca; cuio nombramiento hizo contra expresas disposiciones reales del reino" ${ }^{67}$. En fin, había cortado tres dedos con un hacha a otro descendiente legítimo de curacas, causándole la muerte, entre otros hechos de violencia. Como en otros pleitos donde se ventilaron conflictos de este estilo, se entremezclaban en este usurpaciones de tierras ${ }^{68}$ y presiones por conseguir que los indios cumplieran traba-

65 Presentación de Cáceres al alcalde ordinario de segundo voto. San Luis de Nodolma, 25-I-1779. AHPC, Escribanía 2, legajo 58 , expediente 5 , f. $12 \mathrm{v}$.

66 A la que Córdoba rindió cuentas hasta 1767. Véase Punta, 1997: 144.

67 Presentación de Prudencio Malla, Faustino Amalla y Domingo Amalla al teniente de oficiales reales. Córdoba, 15-XI-1782. AHPC, Escribanía 3, legajo 38, expediente 6, f. 3v.

68 Según atestiguaron los pobladores de Salsacate en la revisita de 1785, estaban reducidos a un terreno muy estrecho y reclamaban derechos sobre más tierras. Ferrero, 2017: 60. 
jos temporales en las estancias de los jueces ${ }^{69}$, pero este caso se destaca sobre otros por la reiteración de las agresiones contra autoridades indígenas.

La réplica del pedáneo fue idéntica a la del cuadrillero en el caso anterior. De Prudencio Malla Quevedo decía que era un "mulato intruso" y que se había cambiado el apellido para pasar por "indio natural". Afirmó que "en el dia apenas se reconosen dos indios legitimos, siendo los mas mulatos foraneos que se habrigan en el pueblo", quienes no eran contenidos por "sus propios jueses a quienes han insultado dandoles de puñaladas... asi lo acredita la carta de su actual alcalde escrita a su protector don Francisco Uriarte" 70 . Se excusaba, en virtud de ello, de haber perseguido "en ocasiones" los excesos de los indios "y a los delinquentes que se han abrigado de aquel pueblo", siempre fuera del territorio de los pueblos, en campos privados y caminos donde alcaldes de la hermandad y jueces pedáneos podían arrogarse jurisdicción.

El testimonio del capitán recaudador Joaquín de Güemes Campero reveló otra vía por la que Quevedo se inmiscuía en el nombramiento de autoridades en el pueblo: había destituido de su cargo de alcalde a Prudencio Malla y, en su lugar, había nombrado a otro sujeto, sin consultar al capitán recaudador como era costumbre ${ }^{71}$. Recordemos que los capitanes recaudadores presidían las elecciones de alcaldes y eran los habitualmente comisionados por el gobernador para sugerir los candidatos al cacicazgo en caso que no lo hubiere de sangre y para dar a los caciques posesión de su cargo. Al ser el segundo eslabón en la cadena de recaudación del tributo, los capitanes tenían la posibilidad de denunciar las faltas e irregularidades de los curacas, incluso pedir su remoción y sugerir un reemplazante. También los jueces pedáneos denunciaban a los curacas por no cumplir con sus obligaciones de mantener al pueblo en vida política y cristiana y pagar puntualmente el tributo, con lo cual a veces lograron que el gobernador intendente les instruyera para hacer la sumaria información. Esta era una de las formas más frecuentes en que se inmiscuían en los pueblos y tejían alianzas con los indios que promovían en los cargos de alcalde y cacique. Allí tallaba la relación entre pedáneos y capitanes recaudadores, que así como en Salsacate por estos años era de cautelosa distancia, en otros casos resultaba ser francamente hostil, salvo que la misma persona ejerciera los dos empleos simultáneamente, en cuyo caso la capacidad de intervención del juez pedáneo quedaba prácticamente legalizada.

Dentro de esas tramas, los indios que aspiraban a obtener cargos de autoridad también tejían sus alianzas. En Salsacate, Miguel Funes se trasladó a la hacienda del recaudador Güemes Campero, donde se presentó como alcalde interino del pueblo, en compañía de seis indios que se ofrecieron para ser empadronados como tributarios. Güemes Campero, reconociendo al alcalde "mucho empeño en arreglar dicho pueblo", pidió al teniente de oficiales reales que se esforzara por lograr su confirmación y que al "lejitimo curaca se le de a conozer su curaquia y de esta suerte se bera si estos naturales se sujetan a pagar dichas tasas y a formalizarse dicho pueblo". El encuentro dio ocasión una vez más a Güemes Campero

69 Los tres indios denunciantes dijeron que el capitán recaudador Güemes Campero se había negado a darles recibos del pago de la tasa y los amenazó con prisión para forzarlos a construir un potrero para él.

70 Presentación de Quevedo al teniente de gobernador y justicia mayor Antonio de la Quintana. Córdoba, 8-V1783. AHPC, Escribanía 3, legajo 38, expediente 6, f. 16v.

71 No queda claro si este nombramiento de alcalde recibió aceptación formal de la comunidad o fue revalidado en una elección posterior. 
a presionar a los indios recién empadronados y deudores de la tasa para que le sirvieran en su estancia ${ }^{72}$.

Otros expedientes criminales hacen referencia a ese tipo de intervenciones indirectas y más o menos encubiertas de los alcaldes de la hermandad y jueces pedáneos. Por ejemplo, en 1786 el juez pedáneo Pedro Miguel Bringas y Zeballos informó haber recibido repetidas quejas contra el cacique de Nono Xavier Charras, por albergar en su pueblo gente perniciosa, dedicada a saltear caminos, al juego y al amancebamiento, lo que fue corroborado por el cura vicario del partido. Así, el juez pedáneo logró que el gobernador intendente lo comisionara para hacer la sumaria, apresar a quienes resultaran reos, remitirlos a la cárcel de la ciudad y embargar sus bienes. La sumaria fue remitida por el intendente al juzgado del alcalde ordinario de primer voto quien (con dictamen del teniente asesor) falló que el año transcurrido en prisión era suficiente pena para el curaca y no lo destituyó ${ }^{73}$. Citado a declarar un teniente de milicias residente en la zona, relató que el tiempo que ofició de alcalde de la hermandad había reconvenido al cacique Xavier Charras en repetidas ocasiones, que reprehendiese los robos y amancebamientos en su casa y pueblo. Mediar ante las autoridades étnicas por conflictos con los vecinos era otra vía por la que las justicias rurales anudaban relaciones.

\section{Conclusión: Acerca de la jurisdicción sobre indios, mestizos y castas}

En los casos examinados queda de manifiesto que la jurisdicción criminal sobre la gente considerada "de otras clases" o de "sangre mezclada" que residía en los pueblos de indios de manera permanente o como parte de sus ciclos habituales de movilidad (los que eran denominados como intrusos o agregados) fue un punto nodal de fricción y un asunto sujeto a contiendas de interpretación de los textos legales y a disputas de poder entre autoridades indígenas y españolas o hispanocriollas. Desde el punto de vista normativo, podemos plantear que los foráneos residentes en los pueblos, así como los indios reducidos cuando transitaban fuera de sus pueblos -en campos privados y caminos- configuraban zonas grises, no prescriptas y, en el primer caso, ni siquiera previstas en el modelo de gobierno colonial, donde por consiguiente autoridades españolas e indígenas podían disputarse sus respectivas jurisdicciones ${ }^{74}$.

Estudios que registran este tipo de contiendas en otros espacios apuntan en el mismo sentido. En Santiago del Estero se presentaron situaciones similares de intrusión de alcaldes de la hermandad en pueblos de indios, a título de persecución de "mulatos", a fines del siglo XVIII, que fueron enfrentados por los alcaldes indígenas como un intento de avasallar su jurisdicción ${ }^{75}$. En la intendencia de La Paz, Thomson observa que la multiplicación de los caciques españoles (o mestizos) coincidió con la

72 Carta del recaudador Joaquín de Güemes Campero al juez oficial real y administrador general de la real renta de tabaco. Hacienda de Yerbabuena, 12-VI-1783. AHPC, Escribanía 3, legajo 38, expediente 6, f. 20r.

73 Sentencia del alcalde ordinario de primer voto en juicio criminal contra el cacique de Nono. Córdoba, 02-XI1786. AHPC, Escribanía 3, legajo 43, expediente 11.

74 Posiblemente pueda decirse lo mismo de la jurisdicción civil; al no haber hallado registros escritos de juicios verbales de los jueces rurales sobre el tipo de pequeños delitos o contravenciones que eran de su competencia, solo podemos plantearlo a título de hipótesis.

75 Véase el estudio de Farberman, 2004; si bien no se centra específicamente en el problema de las jurisdicciones, da cuenta de un conflicto de este tipo. 
proliferación de los alcaldes pedáneos, quienes "se convirtieron en los primeros funcionarios estatales no indígenas que ejercieron autoridad judicial en los pueblos de indios". Según el autor, uno de los artículos de la ROI, que estipulaba que los puestos de alcaldes pedáneos fueran elegidos en los pueblos con muchos residentes españoles, se tomó para justificar la introducción de los alcaldes pedáneos en los pueblos de indios, pero esto solo pudo suceder con la complicidad de la burocracia colonial ${ }^{76}$.

La presencia de forasteros integrados individualmente o en grupos a los pueblos con anuencia de las autoridades indígenas nos remite al problema de las estrategias de supervivencia y recreación de vínculos dentro de las comunidades indígenas. La incorporación de estos recién llegados era una situación común en jurisdicciones como Córdoba, donde la movilidad de la población era acentuada y los pueblos de indios que sobrevivieron estaban creciendo en el siglo XVIII en buena medida gracias a su permeabilidad para recibir foráneos, especialmente quienes se hacían tributarios durante el tiempo que residían en la comunidad ${ }^{77}$. Según indican los casos tratados, cuando esos forasteros fueron identificados no como indios originarios de esos u otros pueblos de reducción, sino como mestizos o gente de castas, habilitaron a alcaldes de la hermandad, jueces pedáneos y sus auxiliares -cuando no se agregaba también el cura doctrinero- para entrometerse en la jurisdicción y en el gobierno interno de los pueblos. Para resumir los argumentos, endilgaban a estos foráneos el introducirse en los pueblos al abrigo de las autoridades étnicas con el objeto de escapar de las justicias españolas, y a los curacas el recibirlos para engrosar el número de tributarios y demandar más tierras. Leído a contrapelo, es plausible que el ponerse bajo jurisdicción de autoridades indígenas redundara en un beneficio para la población campesina, crecientemente hostigada en el siglo XVIII por las autoridades españolas en el campo ${ }^{78}$. En nuestra extensa revisión de los archivos judiciales no encontramos disputas por jurisdicción sobre indios desvinculados de sus pueblos, por lo que podemos arriesgar la hipótesis que estos quedaron -sin discusión- sujetos a las autoridades de la república de "españoles".

Había por lo menos dos situaciones que daban a las justicias españolas un mayor margen de acción legal en las comunidades indígenas: cuando eran facultadas por autoridades regias o capitulares para ejercer comisiones y, más aún, cuando obtenían el empleo de capitán recaudador de tributo, en cuyo caso la duplicación de funciones les permitía, no ejercer justicia -porque el capitán no tenía vara- pero sí denunciar incumplimientos de los deberes de las autoridades étnicas y proponer candidatos para su reemplazo. En ese sentido, la intrusión de los vecinos que portaban rotativamente las varas de justicia en el campo o ejercían como sus auxiliares de policía respondía, previsiblemente, a intereses concretos vinculados a tierras, agua, pastos y mano de obra y se insertaba en tramas de conflictos políticos locales. Nos interesa subrayar que también buscaron debilitar a los curacas y cabildos indígenas, en un contexto donde creemos que estos se vieron fortalecidos por la desaparición de la encomienda privada, las funciones de justicia y recaudación de tributo ganadas en esa transición, y por el crecimiento y dinamismo de sus comunidades que se percibe en la mayoría de los pueblos.

\footnotetext{
76 Thomson, 2006: 287-288.

77 Estas prácticas de movilidad han sido detalladamente estudiadas por Ferrero, 2017.

78 Punta, 1997; Rustán, 2005; Tell, 2008.
} 
En este punto, es preciso recuperar los estudios sobre tributo y tierras que destacan el rol de los curacas en el empadronamiento de tributarios, la recolección y pago del tributo y las sentencias favorables logradas por caciques y/o cabildos indígenas de pueblos de Córdoba que pleitearon durante largas décadas por sus derechos de tierras y agua en la Audiencia de Buenos Aires ${ }^{79}$. Los casos examinados en este trabajo, referidos a pueblos donde el asedio a los curacas y alcaldes fue recurrente o muy agresivo, apuntan en la misma dirección, sugiriendo que el avance de las justicias españolas sobre la jurisdicción de las indígenas no llevó necesariamente -o al menos por sí solo- a un debilitamiento de estas últimas, quienes movilizaron sus redes dentro y fuera de las comunidades y pusieron una vez más en marcha su capacidad de litigar. En los casos que relevamos no observamos que los jueces superiores (alcaldes ordinarios, gobernadores e intendentes) avalaran el avasallamiento de la jurisdicción civil y criminal de los alcaldes indígenas, indicando también que esa intromisión tuvo un éxito -cuanto más- relativo.

\section{Referencias bibliográficas}

Agüero, Alejandro. Castigar y perdonar cuando conviene a la república. La justicia penal de Córdoba del Tucumán, siglos XVII y XVIII. Madrid: Centro de Estudios Políticos y Constitucionales, 2008.

Arcondo, Aníbal. El ocaso de una sociedad estamental. Córdoba entre 1700 y 1760. Córdoba: Universidad Nacional de Córdoba, 1992.

Assadourian, Carlos S. "Los señores étnicos y los corregidores de indios en la conformación del estado colonial". En Transiciones hacia el sistema colonial andino, por Assadourian, Carlos S. Lima: El Colegio de México - Instituto de Estudios Peruanos, 1994, 209-292.

Barriera, Darío. "Instituciones, justicias de proximidad y derecho local en un contexto reformista: designación y regulación de 'jueces de campo' en Santa Fe (GobernaciónIntendencia de Buenos Aires) a fines del siglo XVIII". Revista de Historia del Derecho, $\mathrm{n}^{\mathrm{o}} 44$ (2012), 1-28.

- "La historia de la justicia y las otras historias". En Historia Regional. Enfoques y articulaciones para complejizar una historia nacional, coordinado por Richard-Jorba, Rodolfo - Bonaudo, Marta. La Plata: Editorial de la Universidad Nacional de la Plata, 2014, 19-39.

Bixio, Beatriz - González, Costanza. "Práctica de la justicia y resistencia indígena: Córdoba del Tucumán, siglos XVI y XVII". Colonial Latin American Historical Review, vol. 12, $\mathrm{n}^{\circ} 1$ (2003), 1-24.

Bixio, Beatriz (dir.), González, Costanza - Grana, Romina - Iarza, Valeria (eds.). Visita a las encomiendas de indios de Córdoba 1692-1693. Córdoba: Centro de Estudios Históricos Carlos S. A. Segreti, II tomos, 2009.

Borah, Woodrow. El Juzgado General de Indios en la Nueva España. México: Fondo de Cultura Económica, 1996 [1985].

Carmignani, Leticia. "'Soy en esta provincia muy odiado de los vecinos encomenderos'. El gobernador del Tucumán Alonso de Ribera y su proyecto político (1605-1611)". Memoria Americana. Cuadernos de Etnohistoria, vol. 23, nº 1 (2015), 11-38. 
Castro, Isabel. Transformaciones y continuidades de sociedades indígenas bajo el dominio colonial. El caso del 'pueblo de indios' de Quilino. Córdoba: Alción Editora, 2006.

- "Vuestra Magestad se sirva de ordenar al Governador que no apriete en las ordenanzas del Visitador. Gobierno colonial y poder local en la Gobernación del Tucumán (1603-1619)". Bibliographica Americana, no 9 (2013), 23-48. Disponible en https://www.bn.gov.ar/ micrositios/revistas/bibliographica/bibliographica-americana-1

- "El oidor de Charcas, Antonio Martínez Luján de Vargas, y la nueva coyuntura a fines de siglo XVII en Tucumán. A propósito de los derechos a la tierra de los pueblos de indios". Memoria Americana. Cuadernos de Etnohistoria, vol. 23, nº 1 (2015a), 39-67.

- "Encomiendas, pueblos de indios y tierras. Una revisión de la visita del Oidor Luján de Vargas a Córdoba del Tucumán (fines siglo XVII)". Estudios del ISHiR, nº 12 (2015b), 82-104. Disponible en http://web2.rosario-conicet.gov.ar/ojs/index.php/revistaISHIR/ article/view/542/584

Cutter, Charles. "Community and the Law in Northern New Spain". The Americas, vol. L, n' 4 (1994), 467-480.

Dainotto, Edgardo. Poder y política en la Córdoba borbónica. Córdoba: Ferreyra Editor, 2012.

Doucet, Gastón. “Los autos del visitador don Antonio Martínez Luján de Vargas”. Revista de Historia del Derecho, $\mathrm{n}^{\circ} 8$ (1980a), 123-153.

- "Introducción al estudio de la visita del oidor don Antonio Martínez Luján de Vargas a las encomiendas de indios del Tucumán". Boletín del Instituto de Historia Argentina y Americana Dr. Emilio Ravignani, n 26 (1980b), 205-246.

Farberman, Judith. "Curacas, mandones, alcaldes y curas: legitimidad, autoridad y coerción en los pueblos de indios de Santiago del Estero, siglos XVII y XVIII". Colonial Latin American Historical Review, vol. 13, no 4, (2004), 367-397.

- "Las márgenes de los pueblos de indios. Agregados, arrendatarios y soldados en el Tucumán colonial. Siglos XVIII y XIX". Nuevo Mundo Mundos Nuevos (2009). Disponible en http://journals.openedition.org/nuevomundo/57474

Ferrero, Paula. Adaptación y resistencia. Estructura interna, tributo y movilidad poblacional en los pueblos de indios de Córdoba en las últimas décadas coloniales. Buenos Aires: Prometeo, 2017.

González, Costanza. “Autoridades étnicas en un contexto de desestructuración: Córdoba entre la fundación y la visita de Antonio Martines Luxan de Vargas". En Visita a las encomiendas de indios de Córdoba 1692-1693, tomo I, dirigido por Bixio, Beatriz y editado por González, Costanza - Grana, Romina - Iarza, Valeria. Córdoba: Centro de Estudios Históricos Carlos S. A. Segreti, 2009, 63-114.

Guerrero, Andrés. Administración de poblaciones, ventriloquía y transescritura. Análisis históricos: estudios teóricos. Lima: FLACSO Ecuador - Instituto de Estudios Peruanos, 2010.

Honores, Renzo. "La asistencia jurídica privada a los señores indígenas ante la Real Audiencia de Lima, 1552-1570". XXIV International Congress of the Latin American Studies Association, 2003. Disponible en http://asa.international.pitt.edu/Lasa2003/ HonoresRenzo.pdf.

Kagan, Richard L. Pleitos y pleiteantes en Castilla, 1500-1700. Salamanca: Junta de Castilla y León, 1991.

Katz, Friedrich (comp.). Revuelta, rebelión y sublevación. La lucha rural en México del siglo XVI al siglo XX. México: Era, 2004 [1990].

Kellogg, Susan. Law and the Transformation of Aztec Culture, 1500-1700. Norman: University of Oklahoma Press, 1995. 
Levillier, Roberto. Correspondencia de la ciudad de Buenos Aires con los reyes de España 1615-1635, tomo II. Madrid - Buenos Aires: Municipalidad de Buenos Aires - Biblioteca del Congreso Argentino, 1918.

Lorandi, Ana María. "El servicio personal como agente de desestructuración en el Tucumán colonial”. Revista Andina, no 1 (1988), 135-173.

- "Introducción". En Los pueblos de indios del Tucumán colonial: pervivencia y desestructuración, compilado por Farberman, Judith - Gil, Raquel. Quilmes: Universidad Nacional de Quilmes Ediciones - Editorial de la Universidad Nacional de Jujuy, 2002, 9-14.

Mumford, Jeremy. "Litigation as Ethnography in Sixteenth-Century Peru: Polo de Ondegardo and the Mitimaes". Hispanic American Historical Review, vol. 88, n I (2008), 5-40. DOI: http://dx.doi.org/10.1215/00182168-2007-077

Owensby, Brian. Empire of Law and Indian Justice in Colonial Mexico. Stanford: Stanford University Press, 2008.

Palomeque, Silvia. "El sistema de autoridades de pueblos de indios y sus transformaciones a fines del período colonial. El partido de Cuenca". Memoria Americana. Cuadernos de Etnohistoria, no 6 (1997), 9-47.

- "La 'ciudadanía' y el sistema de gobierno en los pueblos de Cuenca (Ecuador)". Cuadernos de Historia Latinoamericana, no 8 (2000a), 115-141.

- "El mundo indígena. Siglos XVI-XVIII". En Nueva Historia Argentina, dirigido por Tandeter, Enrique. Buenos Aires: Sudamericana, 2000b, tomo II, 87-143.

Piana, Josefina. Los indígenas de Córdoba bajo el régimen colonial. Córdoba: Edición de la autora, 1992.

Punta, Ana Inés. Córdoba borbónica. Persistencias coloniales en tiempo de reformas (17501800). Córdoba: Universidad Nacional de Córdoba, 1997.

- "Adenda. Líneas de trabajo e investigaciones que siguieron a Córdoba Borbónica". En Córdoba borbónica. Persistencias coloniales en tiempo de reformas (1750-1800), por Punta, Ana Inés. Córdoba: Universidad Nacional de Córdoba, $2^{a}$ ed., 2009, 339-355.

Recopilacion de leyes de los reynos de las Indias, mandadas imprimir y publicar por la Magestad católica del rey don Carlos II [1680], tomo II. Madrid: Boix editor, 1841. Disponible en https://archive.org/stream/bub_gb_428DAAAAQAAJ\#page/n0/mode/2up

Rustán, María Elizabeth. De perjudiciales a pobladores de la frontera. Poblamiento de la frontera sur de la Gobernación Intendencia de Córdoba a fines del siglo XVIII. Córdoba: Ferreyra Editor, 2005.

San Martino de Dromi, Laura. Documentos constitucionales argentinos. Madrid: Ediciones Ciudad Argentina, 1994.

Sarabia, María Justina. Francisco de Toledo. Disposiciones gubernativas para el virreinato del Perú 1575-1580, tomo II. Sevilla: Escuela de Estudios Hispanoamericanos, 1989.

Serulnikov, Sergio. Conflictos sociales e insurrección en el mundo colonial andino. El norte de Potosi en el siglo XVIII. Buenos Aires: Fondo de Cultura Económica, 2006.

Stern, Steve. Los pueblos indígenas del Perú y el desafío de la conquista española. Huamanga hasta 1640. Madrid: Alianza, 1986.

Storni, Carlos. "Notas acerca de los alcaldes de hermandad y los jueces comisionados. Dos breves reglamentos". En Investigaciones sobre historia del derecho rural argentino, por Storni, Carlos. Buenos Aires: Instituto de Investigaciones de Historia del Derecho, 1997a, 99-112.

- “Algo más sobre los jueces comisionados". En Investigaciones sobre historia del derecho rural argentino, por Storni, Carlos. Buenos Aires: Instituto de Investigaciones de Historia del Derecho, 1997b, 113-134. 
Tell, Sonia. Córdoba rural, una sociedad campesina (1750-1850). Buenos Aires: Prometeo, 2008.

- "Expansión urbana sobre tierras indígenas. El pueblo de La Toma en la Real Audiencia de Buenos Aires". Mundo Agrario. Revista de Estudios Rurales, vol. 10, no 20 (2010). Disponible en http://www.redalyc.org/articulo.oa?id=84514811009

- "Conflictos por tierras en los pueblos de indios de Córdoba. El pueblo de San Marcos entre fines del siglo XVII y principios del siglo XIX”. Andes. Antropología e Historia, vol. 23, no 1 (2012), 71-103.

- "En defensa de la autonomía. Gobierno, justicia y reclutamiento en los pueblos de indios de Córdoba (1810-1850)". En Hacer politica. La participación popular en el siglo XIX rioplatense, compilado por Fradkin, Raúl O. - Di Meglio, Gabriel, Buenos Aires. Prometeo, 2013, 127-150.

Tell, Sonia - Castro, Isabel. "El registro y la historia de los pueblos de indios de Córdoba entre los siglos XVI y XIX”. Revista del Museo de Antropología, vol. 4, n 4 (2011), 235-248.

Thomson, Sinclair. Cuando sólo reinasen los indios. La política aymara en la era de la insurgencia. La Paz: Muela del Diablo Editores - Aruwiyiri, 2006.

Yannakakis, Yanna. "Indigenous People and Legal Culture in Spanish America". History Compass, vol. 11, no 11 (2013), 931-947. DOI: http://dx.doi.org/10.1111/hic3.12096

Zorraquín, Ricardo. La organización judicial argentina en el período hispánico. Buenos Aires: Librería del Plata, 1952. 